\title{
Effect of Feeding Transcarpathian Zeolite on Gastrointestinal Morphology and Function in Broiler Chickens
}

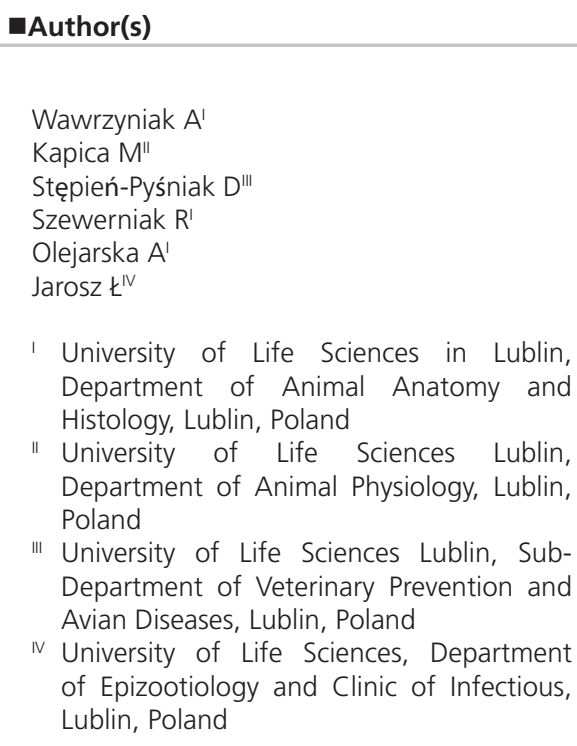

\section{Mail Address}

Corresponding author e-mail address Agata Wawrzyniak

University of Life Sciences in Lublin, Department of Animal Anatomy and Histology, Lublin, Poland

Tel: $\quad$ + 48814456972

Email: agata.wawrzynia@up.lublin.p

\section{-Keywords}

Digestive enzyme, histology, small intestine, zeolite.

\section{ABSTRACT}

Many kinds of feed additives can be used in chicken diets to stimulate intestinal morphological maturation and, consequently, intestinal function. The purpose of this study was to evaluate the effect of zeolite on broiler performance, gut morphology and gut digestive enzyme activity. The one-day old broiler chickens Ross 308 were assigned randomly into 3 groups with 30 birds per treatment. The 3 dietary treatments were: basal diet only (control group), basal diet + $2 \%$ zeolite, basal diet $+3 \%$ zeolite. Morphological and morphometric intestinal assessments were conducted using a light microscope. There was observed increase in villus height, villus perimeter, villus section area and crypt depth throughout duodenum and mid jejunum of the broilers fed zeolite. Supplementation especially with $2 \%$ zeolite was associated with greater villus heights, villus perimeter, villus section area and crypt depth in duodenum and ileum mucosa compared to the controls. The diet with $2 \%$ zeolite also contributed to significant increase proventriculus (pepsin) and pancreas (trypsin, lipase) activity compared to the controls The results suggest that dietary supplementation of zeolite increased feed consumption, intestinal morphology parameters and enzyme activity of gastrointestinal tract in broiler which improved growth performance.

\section{INTRODUCTION}

Zeolite (Clinoptilolite) is a natural crystalline porous mineral. Natural zeolites are crystalline aluminosilicates with unique adsorption, cationexchange (Wu et al., 2013a). Zeolite has a unique structure, which is similar to that of a honeycomb, and each tiny cavity within every piece of zeolite is negatively charged. This allows for positively charged molecules to be pulled in and trapped in their pores (Wu et al., 2013b, Wu et al., 2013a). Due to their biologically neutral structure and their unusual properties, zeolites have been applied to veterinary medicine, agriculture, industry, sanitation and environmental protection (Pavelic et al., 2001). Zeolite can actively adsorb ammonia, carbon dioxide, hydrogen sulfide and mercaptans, remove toxins, absorb aflatoxin and create changes in immunological responses (Khambualai et al., 2009). Microelements present in zeolite, can enhance mineral metabolism and increase the content of minerals in the tissues. Zeolite is capable of getting involved in the exchange. The ion composition of the chyme changes, zeolite can normalize the body $\mathrm{pH}$ and optimize the activity of digestive enzymes (Pavelic et al., 2001). Zeolites absorb toxins and Escherichia coli enterotoxins, and these adsorbents have a beneficial role, especially for prevention from spontaneous diarrhea by reducing enterotoxin activity. Zeolites improve the ability to resist some diseases, promote some positive effects as an antioxidant and may have an antiviral outcome (Papaioannou et al., 2004).They are also used as 
Wawrzyniak A, Kapica M,

Stępień-Pyśniak D, Szewerniak R,

Olejarska A, Jarosz $t$

\section{Effect of Feeding Transcarpathian Zeolite on Gastrointestinal Morphology and Function in Broiler Chickens}

a feed additive (Pavelic et al., 2001, Olver, 1997, Martin-Kleiner et al., 2001, Khambualai et al., 2009). Numerous studies have proved that zeolite added as a dietary supplement to the rations of cattle, pigs and poultry results frequently in beneficial weight gains and lower susceptibility to disease showing regular digestions as well as an increase in appetite of animals because zeolites slow down the passage rate of digesta through the digestive tract and control the release of nutrients in the small intestine (Papaioannou et al., 2002, Ural et al., 2013, Valpotic et al., 2016). Zeolite has a beneficial effect on feed components owing to the fact that they improve energy and protein retention. Zeolite influences nutrient absorption in the digestive tract allowing for better results than other supplements (Wu et al., 2013a). Zeolite as a dietary supplement in poultry showed that animals mostly grow faster, and the number and severity of intestinal diseases are reduced (Pavelic et al., 2001). A natural zeolite with enhanced physicochemical properties, is the basis of the dietary supplements which interact with the cellular immune system. Adding zeolites to broiler diets plays a significant role in the final phase of nutrient digestion and assimilation resulting in the improved body weight gain, feed conversion ratio, growth rate morphology of the small intestine (Incharoen et al., 2010a, Mumpton, 1999). The morphological changes of the intestinal villi are dependent on the presence of digested nutrients in the small intestinal lumen. The morphometric analysis is widely used in gastrointestinal research since it is a quantitative assessment and thus, more reliable and reproducible than a subjective assessment, which is especially important. Simultaneous application of morphometric and enzymatic analyses provides important information for improvement intestinal health condition in animals (Mumpton, 1999). In this research, for the first time, the effect of Transcarpathian zeolite on the morphology of the small intestine and enzyme activity in gastrointestinal tract in male broiler chickens was studied.

\section{MATERIALS AND METHODS}

\section{Ethical Approval of the Study Protocol}

The experimental procedures used in this study were approved by The 2nd Local Ethics Committee on Animal Experimentation in Lublin in Resolution No 15/2014 and performed in accordance with the Guiding Principles for the Care and Use of Animals in Research.

\section{Animals and Feeding}

The one-day old broiler chickens Ross 308 were assigned randomly into 3 groups with 30 birds per treatment (90 birds). The 3 dietary treatments were: basal diet only (control group), basal diet $+2 \%$ zeolite, basal diet $+3 \%$ zeolite. All birds were fed with a starter diet from 1 to 14 days followed by a grower I and II diet from 15 to 35 days and from 36 to 40 day finisher diet (Table 1). The experiment was conducted in a designated area of a commercial poultry house. Birds were kept in three identical pens $(2.5 \times 1.5 \times 1.5 \mathrm{~m})$, which were constructed during technical break. Each treatment had three replicates with 10 birds per cage. The initial temperature of $32^{\circ} \mathrm{C}$ was gradually reduced according to the age of the birds, reaching $20^{\circ} \mathrm{C}$ at the end of the experiment. A continuous lighting program was provided during the experiment. The zeolite (generously supplied by Andalusia company, Poland) grain size was within the range of 0.2 to $0.5 \mathrm{~mm}$.

Table 1 - Formulation and calculated composition of broiler diets (basal diet)

\begin{tabular}{|c|c|c|c|c|}
\hline Ingredients of feed $\mathrm{g} / \mathrm{kg}$ & $\begin{array}{c}\text { Broiler starter } \\
0-14 \text { days }\end{array}$ & $\begin{array}{c}\text { Broiler grower I } \\
15-24 \text { days }\end{array}$ & $\begin{array}{c}\text { Broiler grower II } \\
25-5 \text { days before slaugther }\end{array}$ & $\begin{array}{c}\text { Broiler finisher } \\
\text { last week before slaughter }\end{array}$ \\
\hline Corn & 200 & 200 & 300 & 200 \\
\hline Wheat & 388 & 431 & 351 & 503 \\
\hline Soybean meal & 340 & 300 & 270 & 230 \\
\hline Soybean oil & 30 & 30 & 40 & 35 \\
\hline Limestone & 15 & 12 & 12 & 10 \\
\hline Cytromix plus & 2 & 2 & 2 & 2 \\
\hline aFarmix BR ST 2.5\% & 25 & - & - & - \\
\hline bFarmix BR. GR. 2.5\% & - & 25 & 25 & - \\
\hline 'Farmix BR. GR. 2.5\% BuM & - & - & - & 20 \\
\hline
\end{tabular}

a content of vitamins and minerals per 1 kg of Starter: Mn 100 mg, I 1 mg, Fe 40 mg, Cu 16 mg, Se 0.15 mg, vitamin A 15000 UI, vitamin D 35000 UI, vitamin E 75 mg, vitamin K 3 4 mg, vitamin B 13 mg, vitamin B 28 mg, vitamin B 65 mg, vitamin B12 0,016 mg, biotin 0.2 mg, folic acid 2 mg, nicotinic acid 60 mg, pantothenic acid 18 mg, choline 1800 mg; ${ }^{\mathrm{b}}$ content of vitamins and minerals per 1 kg of Grower: Mn 100 mg, I 1 mg, Fe 40 mg, Cu 16 mg, Se 0,15 mg, vitamin A 12000 UI, vitamin D 35000 UI, vitamin E 50 mg, vitamin K 3 3 mg, vitamin B 12 mg, vitamin B 26 mg, vitamin B6 4 mg, vitamin B12 $0.016 \mu$ g, biotin 0.2 mg, folic acid 1.75 mg, nicotinic acid 60 mg, pantothenic acid 18 mg, choline 1600 mg; c content of vitamins and minerals per 1 kg of Finisher: Mn 100 mg, I 1 mg, Fe 40 mg, Cu 16 mg, Se 0.15 mg, vitamin A 12000 Ul, vitamin D 35000 UI, vitamin E 50 mg, vitamin K 3 2 mg, vitamin B 12 mg, vitamin B 25 mg, vitamin B 63 mg, vitamin B12 0.011 gg, biotin 0,05 mg, folic acid 1.5 mg, nicotinic acid 35 mg, pantothenic acid 18 mg, choline 1600 mg; 
Wawrzyniak A, Kapica M,

Stępień-Pyśniak D, Szewerniak R,

Olejarska A, Jarosz $t$
Effect of Feeding Transcarpathian Zeolite on Gastrointestinal Morphology and Function in Broiler Chickens
The zeolite contained at least $87 \%$ of clinoptilolite as the active substance. Chemical composition of tested clinoptilolite included $67.07 \% \quad \mathrm{SiO}_{2}, 12.4 \% \quad \mathrm{Al}_{2} \mathrm{O}_{3}$, $2.09 \% \mathrm{CaO}, 2.8 \% \mathrm{~K}_{2} \mathrm{O}, 0.9 \% \mathrm{Fe}_{2} \mathrm{O}_{3} 0.72 \% \mathrm{MgO}$, $2.05 \% \mathrm{Na}_{2} \mathrm{O}, 0.19 \% \mathrm{TiO}_{2}, 0.04 \% \mathrm{MnO}, 0.014 \% \mathrm{P}_{2} \mathrm{O}_{5}$. The feed and water were provided ad libitum for a period of 40 days. The feeds were weighed daily for 40 days to determine feed consumption.

The birds had no developmental disorders and detectable diseases that could cause any problem in the histological architecture of gastrointestinal tract. A random sample of 90 birds for each group was weighed individually upon arrival (day 0). Next, a random sample of 90 birds in each group was individually weighed at $7,14,21,28,35$ and 40 days of age. Feeds refusals of each group were recorded every day.

At the end of the experimental period, 10 male broiler chickens from each group were chosen. Following the decapitation the entire gastrointestinal tract was removed for morphometry analysis and tissue sampling. The organs under examination were weighed (proventriculus, pancreas, duodenum, prox jejunum, mid jejunum, distal jejunum. Wholethickness samples of the duodenum, proximal (25\%), middle (50\%) and distal (75\%) part of jejunum (length from ligament of Treitz), and ileum were washed in a mixture of $0.5 \mathrm{M}$ phosphate buffered saline $\mathrm{pH} 7.6$ for histological analysis. The corresponding $15-\mathrm{cm}$ long intestine segments were gently scraped to collect the mucosa for enzyme activity analysis.

\section{Preparation of Histological Samples}

Histological specimens were prepared using the paraffin method. The intestine samples were immediately fixed in fresh $4 \%$ buffered formaldehyde, dehydrated in growing concentration of ethyl alcohol, cleared in xylene, and embedded in paraplast (SigmaAldrich). The tissue sections were then generally cut at a width of approximately $5 \mu \mathrm{m}$ for paraffin blocks, collected onto uncoated glass slides and stained with Delafield's Haematoxylin, counterstained with Eosin (H\&E) and closed with the use of DPX (SigmaAldrich). The samples were analysed morphologically and photographed under an Leica DMI6000 B light microscope equipped with a Leica DFC450C digital camera.

\section{Morphometric Analysis}

The morphometric analysis was applied to measure intestinal villi and intestinal glands of 5 parts of the small intestine (duodenum, jejunum /proximal, middle, distal/, ileum) in the 3 study groups only in males. The following parameters were estimated: the height of the villus $(\mathrm{VH})$, the width of the villus (VW), villus section area (VSA) and villus perimeter (girth of villi) (VP), number of villi per $1 \mathrm{~cm}$ of the mucous membrane $(\mathrm{VN})$, number of crypts per $1 \mathrm{~cm}$ of the mucous membrane (CN) with magnification $\times 10$, the depth of the crypt $(C D)$, and the thickness of the muscular layer (MT) (from the villus apex to the intestinal submucosa) with magnification $\times 40$. Moreover, there were established: ratios of villus height:crypth depth (VH/CD), mucosa thickness (MT). The whole morphometric parameters were determined automatically under a light microscope Leica DM6000 B (Leica Camera AG, Wetzlar, Germany). 40 measurements per animal were randomly made by a blind observer for each variable in each segment using Leica LAS V4.4 Interactive Measurement Module. The digital images were captured with a high-resolution camera Leica DFC 450C coupled to a light microscope Leica DM6000 B using LAS 4.4 Core software.

In order to obtain valuable data variation coefficients (SD/mean) were determined and on their basis each portion of the intestine was sampled in every animal according to the following protocol: at least 25 villi for measurement of their height and at least 50 for measurement of their width. The mean values of each measured parameter for each portion of the intestine in each animal were evaluated and entered as raw data on the database.

\section{Enzymatic Activity Assay}

Proventriculus was washed with cold water to remove traces of food and immersed in $2 \% \mathrm{NaHCO}_{3}$ solution for 10-15 min. Mucosa separated from the muscle layers was disintegrated in a glass homogenizer to the final volume of $10 \mathrm{ml} / \mathrm{g}(\mathrm{v} / \mathrm{w})$ of tissue using sodium phosphate buffer $0.01 \mathrm{~mol} / \mathrm{l}$ at $\mathrm{pH} 7.5$. The homogenates were centrifuged at $5000 \mathrm{xg}$ for $15 \mathrm{~min}$ at $4^{\circ} \mathrm{C}$ and the supernatants were stored overnight at $4^{\circ} \mathrm{C}$.

Pepsin activity was assayed following the method of spectrophotometric stop rate determination (Wislinski et al., 1995). One unit will produce a $\Delta$ A280 of 0.001 per minute at $\mathrm{pH} 2.0$ and $37^{\circ} \mathrm{C}$, measured as TCAsoluble products using hemoglobin as a substrate. Pancreas was homogenized in the $500 \mathrm{mM}$ Tris- $\mathrm{HCl}$ buffer $(1: 20 \mathrm{w} / \mathrm{v})$ containing $50 \mathrm{mM} \mathrm{CaCl}_{2}, \mathrm{pH}$ 8.0, at $4^{\circ} \mathrm{C}$. The homogenate was centrifuged at $14.000 \mathrm{x}$ $\mathrm{g}$ for $30 \mathrm{~min}$, at $4^{\circ} \mathrm{C}$. The remaining supernatant was frozen in liquid nitrogen and store frozen at $-70^{\circ} \mathrm{C}$ until the activity of the other enzymes was determined. Trypsin activity was monitored by the amount of released $p$-nitroanilide ( $p N A$ ) from a specific substrate, 
Wawrzyniak A, Kapica M, Stępień-Pyśniak D, Szewerniak R, Olejarska A, Jarosz $t$

measuring spectrophotometric units at $405 \mathrm{~nm}$ (A405) (Trypsin Activity Assay Kit, BioVision). A standard curve was built on two-fold serial diluted concentrations of the substrate p-NA from 20 to $2 \mathrm{nmol} /$ well. $10 \mathrm{nM}$ trypsin was used as a positive control. Trypsin activity was calculated according to the formula suggested in the manufactor's instruction. The pancreatic amylase activity was determined using ethylidene-p-nitrophenol (pNP)maltoheptaoside as the substrate (Amylase Activity Assay Kit, BioVision). Once the substrate is specifically cleaved by $\alpha$-amylase activity, the smaller fragments produced are acted upon by the $\alpha$-glucosidases which causes the release of the chromophore that is then to be measured at $405 \mathrm{~nm}$. Lipase activity was assayed using a lipase assay kit (BioVision, Milpitas, CA, USA). In this assay lipase hydrolyzed a triglyceride substrate to form glycerol which was quantified enzymatically via monitoring a linked change in the OxiRed probe absorbance at $570 \mathrm{~nm}$.

The mucosa from duodenum, proximal, middle, and distal jejunum was scraped using a microscope slide, deep frozen, and stored at $-80^{\circ} \mathrm{C}$. The total protein content and activities of the main brush border enzymes in mucosa scrapings were determined. After thawing, $1 \mathrm{~g}$ of mucosa was homogenized with $5 \mathrm{ml}$ of distilled water and centrifuged for $5 \mathrm{~min}$ at 1.000 $\times g$ at $4^{\circ} \mathrm{C}$. The total protein content of supernatant was determined in accordance with the Lowry method modified to be performed in 96-microwell (Matyjek et al., 2004). Maltase and sucrase activities were determined (Dahlqvist, 1984) with minor modifications. Enzyme activities were presented as enzymatic units (U) per milligram of protein. One enzymatic unit expressed micromoles of glucose or p-nitroanilide released per minute of reaction at $37^{\circ} \mathrm{C}$ (Kotunia et al., 2004).
Effect of Feeding Transcarpathian Zeolite on Gastrointestinal Morphology and Function in Broiler Chickens

\section{Statistical Analysis}

The data were expressed as their means \pm standard errors of mean (SEM). One-way parametric ANOVA followed by the Tukey-Kramer post-test was used to check statistical differences between the animal groups (InStat ${ }^{\circledR}$ v.3.06, GraphPad Software Inc., USA). In all statistical analyses $p<0.05$ was taken as the level of significance.

\section{RESULTS AND DISCUSION}

Table 2 shows the feed consumption and average daily feed consumption of broilers in control and experimental groups. There was a noticeable increase of feed consumption in broilers which received dietary supplementation of $2 \%$ and $3 \%$ of zeolite compared to the control. There was observed increase of body weight in animal of experimental groups.

The measurements of tunica mucosa showed a significant increase in villus height $(\mathrm{VH})$ in the duodenum, mid jejunum and ileum in broilers chicken male which received dietary supplementation of $2 \%$ zeolite compared to the control. A significant decrease was observed in the proximal part of jejunum in both experimental groups compared to the control. Decline in villus width (VW) in the mucosa of the duodenum, proximal, mid and distal jejunum was observed to be similar in the both experimental groups compared to the control. There was also a tendency towards an increase in a number of villi (VN), calculated per $1 \mathrm{~cm}$ of the mucous membrane, and in the villus perimeter (VP) in all part of the intestine, in the group which received $2 \%$ and $3 \%$ zeolite, compared to the control. There was observed a significant increase of villus perimeter (VP) in duodenum, proximal, mid jejunum

Table 2 - Feed consumption and average daily feed consumption of broilers according to treatment and age. Body weight initial and finish.

\begin{tabular}{|c|c|c|c|c|}
\hline \multirow{2}{*}{ Traits } & \multirow{2}{*}{ Period (days) } & \multicolumn{3}{|c|}{ Treatment groups } \\
\hline & & Control & $2 \%$ & $3 \%$ \\
\hline \multirow{5}{*}{ Feed consumption (g) } & $0-14$ & 576.7 & 643.5 & 609.3 \\
\hline & $15-24$ & 987.5 & 1049.1 & 1048.9 \\
\hline & $25-35$ & 1645.5 & 1677.0 & 1625.8 \\
\hline & $36-40$ & 713.6 & 766.8 & 733.1 \\
\hline & Overall & 3923.3 & 4136.4 & 4016.8 \\
\hline \multirow{5}{*}{$\begin{array}{l}\text { Average daily } \\
\text { feed consumption (g) }\end{array}$} & $0-14$ & 41.2 & 45.9 & 43.5 \\
\hline & $15-24$ & 98.8 & 104.9 & 104.8 \\
\hline & $25-35$ & 149.6 & 152.5 & 147.8 \\
\hline & $36-40$ & 178.4 & 191.7 & 183.3 \\
\hline & Overall & 117.0 & 123.8 & 119.9 \\
\hline \multirow{2}{*}{ Body weight (g) } & initial & 42 & 42 & 42 \\
\hline & finish & 2230 & 2288 & 2317 \\
\hline
\end{tabular}

Treatment groups: Control (basal diet only), 2\% (basal diet $+2 \%$ zeolite), 3\% ( basal diet $+3 \%$ zeolite). 
Wawrzyniak A, Kapica M,

Stępień-Pyśniak D, Szewerniak R,

Olejarska A, Jarosz $\mathrm{t}$
Effect of Feeding Transcarpathian Zeolite on Gastrointestinal Morphology and Function in Broiler Chickens and ileum in the group receiving 3\% zeolite. Only in the distal jejunum was observed a significant decrease of the villus perimeter (VP) in the group receiving 3\% zeolite (Tables 3-7). In the morphometric analysis of the villus section area (VSA) in the group with 2 and $3 \%$ of zeolite, there was observed a significant increase in mid jejunum and ileum compared to the control, while in duodenum only with $2 \%$. In comparison with the control, supplementation of $3 \%$ zeolite VSA showed a significant decrease in the proximal and distal parts of jejunum (Tables 3-7). Supplementation of $2 \%$ zeolite induced a significant increase in the crypt depth (CD) in the entire part of the small intestine compared to the control. In the male broiler chickens which received $3 \%$ zeolite there was observed a significant increase in proximal, mid jejunum and on ileum compared to the control. The analysis of a number of crypts per $1 \mathrm{~cm}$ of the mucous membrane (CN) in the group with $2 \%$ zeolite demonstrated a significant increase in the whole part of the small intestine, except mid jejunum compared to the control. In the group receiving 3\% zeolite a significant increase was observed only in duodenum and distal jejunum compared to the control. However, a significant decrease in the mid jejunum and ileum was observed in this experimental group compared to the control. Mucosa thickness (MT) was significantly

Table 3 - Effects of Zeolite (clinoptilolite) on morphometric parameters in the duodenum of broilers

\begin{tabular}{|c|c|c|c|}
\hline Duodenum & Control & $2 \%$ & $3 \%$ \\
\hline Villus height (VH) & $1637.81 \pm 63.2 \mathrm{a}$ & $2606.20 \pm 105.1 b$ & $1644.03 \pm 94.9 a$ \\
\hline Villus width (VW) & $286.41 \pm 13.8 a$ & $208.72 \pm 11.3 b$ & $215.46 \pm 16.2 b$ \\
\hline Villus number per cm (VN) & $57.30 \pm 5.7 a$ & $64.40 \pm 5.4 a$ & $67.20 \pm 6.3 \mathrm{a}$ \\
\hline Villus primeter (VP) & $2911.96 \pm 166.8 a$ & $3337.43 \pm 239.2 b$ & $3273.09 \pm 168.3 b$ \\
\hline Villus section area (VSA) & $282175.1 \pm 20809.1 \mathrm{a}$ & $380023.6 \pm 22673.5 b$ & $271494.3 \pm 14772.4 \mathrm{a}$ \\
\hline Crypt depth (CD) & $262.50 \pm 13.1 \mathrm{a}$ & $370.92 \pm 16.1 b$ & $270.12 \pm 15.1 \mathrm{a}$ \\
\hline Crypts number per cm (CN) & $89.60 \pm 2.1 \mathrm{a}$ & $108.30 \pm 0.8 b$ & $102.10 \pm 1.9 b$ \\
\hline Villus height (VH): Crypth depth (CD) (VH/CD) & $6.64 \pm 0.4 a$ & $7.25 \pm 0.4 b$ & $6.49 \pm 0.5 a$ \\
\hline Mucosa thickness (MT) & $2025.26 \pm 81.8 a$ & $2984.09 \pm 88.2 b$ & $1883.9 \pm 77.5 a$ \\
\hline
\end{tabular}

Data represent means from 10 replicates per treatment, SEM = Standard error of mean.

Means with different superscript letters in the same line differ significantly

Table 4 - Effects of Zeolite (clinoptilolite) on morphometric parameters in the proximal jejunum of broilers

\begin{tabular}{lccc}
\hline Proximal jejunum & Control & $2 \%$ & $3 \%$ \\
\hline Villus height $(\mathrm{VH})$ & $2248.64 \pm 71.5 \mathrm{a}$ & $1855.48 \pm 122.8 \mathrm{~b}$ & $1651.59 \pm 62.6 \mathrm{c}$ \\
Villus width (VW) & $198.91 \pm 16.3 \mathrm{a}$ & $185.48 \pm 11.1 \mathrm{a}$ & $152.04 \pm 7.6 \mathrm{~b}$ \\
Villus number per cm (VN) & $54.6 \pm 1.2 \mathrm{a}$ & $60.60 \pm 0.9 \mathrm{a}$ & $55.00 \pm 1.2 \mathrm{a}$ \\
Villus primeter (VP) & $3204.78 \pm 336.4 \mathrm{a}$ & $3315.08 \pm 149.8 \mathrm{a}$ & $3686.24 \pm 121.4 \mathrm{~b}$ \\
Villus section area (VSA) & $305335.8 \pm 28624.3 \mathrm{a}$ & $291603.3 \pm 27023.9 \mathrm{a}$ & $263022.7 \pm 8538.8 \mathrm{~b}$ \\
Crypt depth (CD) & $231.88 \pm 30.7 \mathrm{a}$ & $469.77 \pm 22.3 \mathrm{~b}$ & $310.37 \pm 22.1 \mathrm{~b}$ \\
Crypts number per cm (CN) & $97.4 \pm 9.9 \mathrm{a}$ & $142.30 \pm 1.2 \mathrm{~b}$ & $102.57 \pm 10.2 \mathrm{a}$ \\
Villus height (VH):Crypth depth (CD) (VH/CD) & $10.73 \pm 1.0 \mathrm{a}$ & $4.23 \pm 0.4 \mathrm{~b}$ & $5.97 \pm 0.5 \mathrm{c}$ \\
Mucosa thickness (MT) & $2395.79 \pm 55.7 \mathrm{a}$ & $2022.52 \pm 76.5 \mathrm{~b}$ & $2153.50 \pm 61.2 \mathrm{~b}$ \\
\hline
\end{tabular}

Data represent means from 10 replicates per treatment, SEM = Standard error of mean.

Means with different superscript letters in the same line differ significantly

Table 5 - Effects of Zeolite (clinoptilolite) on morphometric parameters in the mid jejunum of broilers

\begin{tabular}{|c|c|c|c|}
\hline Mid jejunum & Control & $2 \%$ & $3 \%$ \\
\hline Villus height (VH) & $1470.24 \pm 51.9 a$ & $1833.42 \pm 38.5 b$ & $1487.13 \pm 60.0 \mathrm{a}$ \\
\hline Villus width(VW) & $197.30 \pm 10.1 \mathrm{a}$ & $171.68 \pm 7.6$ b & $178.17 \pm 6.1 \mathrm{~b}$ \\
\hline Villus number per cm (VN) & $62.70 \pm 8.4 \mathrm{a}$ & $63.70 \pm 4.3 \mathrm{a}$ & $67.60 \pm 11.6 \mathrm{a}$ \\
\hline Villus primeter (VP) & $2602.23 \pm 95.9 \mathrm{a}$ & $3862.89 \pm 43.4 b$ & $3110.83 \pm 98.9 b$ \\
\hline Villus section area (VSA) & $228795.5 \pm 18135.6 \mathrm{a}$ & $320757.1 \pm 16474.4 b$ & $262897.8 \pm 15864.5 \mathrm{a}$ \\
\hline Crypt depth (CD) & $175.24 \pm 9.8 \mathrm{a}$ & $280.28 \pm 29.5 b$ & $212.34 \pm 12.1 \mathrm{c}$ \\
\hline Crypts number per cm (CN) & $235.10 \pm 3.3 a$ & $185.94 \pm 9.7 b$ & $130.45 \pm 3.4 c$ \\
\hline Villus height (VH): Crypth depth (CD) (VH/CD) & $8.95 \pm 0.5 \mathrm{a}$ & $8.65 \pm 0.9 a$ & $7.76 \pm 0.6 b$ \\
\hline Mucosa thickness (MT) & $1798.02 \pm 18 \mathrm{a}$ & $2248.33 \pm 18.8 b$ & $1821.23 \pm 61.0 \mathrm{a}$ \\
\hline
\end{tabular}

Data represent means from 10 replicates per treatment, $\mathrm{SEM}=$ Standard error of mean.

Means with different superscript letters in the same line differ significantly 
Table 6 - Effects of Zeolite (clinoptilolite) on morphometric parameters in the distal jejunum of broilers

\begin{tabular}{lccc}
\hline Distal jejunum & Control & $2 \%$ & $3 \%$ \\
\hline Villus height (VH) & $1320.18 \pm 22.8 \mathrm{a}$ & $1381.10 \pm 27.9 \mathrm{a}$ & $1390.25 \pm 32.1 \mathrm{a}$ \\
Villus width (VW) & $261.30 \pm 16.3 \mathrm{a}$ & $184.14 \pm 12.5 \mathrm{~b}$ & $156.12 \pm 5.9 \mathrm{c}$ \\
Villus number per cm (VN) & $69.60 \pm 6.5 \mathrm{a}$ & $69.70 \pm 6.6 \mathrm{a}$ & $70.20 \pm 8.2 \mathrm{a}$ \\
Villus primeter (VP) & $2849.35 \pm 89.6 \mathrm{a}$ & $2951.56 \pm 74.2 \mathrm{a}$ & $2304.18 \pm 98.9 \mathrm{~b}$ \\
Villus section area (VSA) & $285887.1 \pm 15075.7 \mathrm{a}$ & $292316.5 \pm 12416.9 \mathrm{a}$ & $206988.4 \pm 6339.7 \mathrm{~b}$ \\
Crypt depth (CD) & $206.72 \pm 10.7 \mathrm{a}$ & $265.87 \pm 12.4 \mathrm{~b}$ & $201.90 \pm 14.0 \mathrm{a}$ \\
Crypts number per cm (CN) & $37.40 \pm 0.9 \mathrm{a}$ & $86.50 \pm 1.1 \mathrm{~b}$ & $67.10 \pm 0.9 \mathrm{c}$ \\
Villus height (VH):Crypth depth (CD) (VH/CD) & $6.92 \pm 0.5 \mathrm{a}$ & $6.09 \pm 0.3 \mathrm{a}$ & $7.62 \pm 0.6 \mathrm{~b}$ \\
Mucosa thickness (MT) & $1543.03 \pm 42.7 \mathrm{a}$ & $1648.18 \pm 47.53 \mathrm{~b}$ & $1766.60 \pm 38.8 \mathrm{~b}$ \\
\hline
\end{tabular}

Data represent means from 10 replicates per treatment, SEM = Standard error of mean.

Means with different superscript letters in the same line differ significantly

Table 7 - Effects of Zeolite (clinoptilolite) on morphometric parameters in the ileum of broilers

\begin{tabular}{lccc}
\hline lleum & Control & $2 \%$ & $3 \%$ \\
\hline Villus height (VH) & $1060.38 \pm 14.9 \mathrm{a}$ & $1273.87 \pm 28.6 \mathrm{~b}$ & $1069.06 \pm 35.4 \mathrm{a}$ \\
Villus width (VW) & $184.76 \pm 9.2 \mathrm{a}$ & $189.74 \pm 9.1 \mathrm{a}$ & $188.11 \pm 8.2 \mathrm{a}$ \\
Villus number per cm (VN) & $46.8 \pm 4.2 \mathrm{a}$ & $57.9 \pm 4.95 \mathrm{~b}$ & $57.6 \pm 4.5 \mathrm{~b}$ \\
Villus primeter (VP) & $1045.15 \pm 29.1 \mathrm{a}$ & $1413.14 \pm 48.5 \mathrm{~b}$ & $1226.57 \pm 25.4 \mathrm{~b}$ \\
Villus section area (VSA) & $110515.6 \pm 3659.8 \mathrm{a}$ & $136050.6 \pm 6316.3 \mathrm{~b}$ & $127241.6 \pm 2926.2 \mathrm{~b}$ \\
Crypt depth (CD) & $141.39 \pm 6.1 \mathrm{a}$ & $190.73 \pm 10.5 \mathrm{~b}$ & $164.93 \pm 4.1 \mathrm{~b}$ \\
Crypts number per cm (CN) & $57.0 \pm 0.8 \mathrm{a}$ & $81.6 \pm 1.4 \mathrm{~b}$ & $38.87 \pm 3.9 \mathrm{c}$ \\
Villus height (VH):Crypth depth (CD) (VH/CD) & $7.49 \pm 0.3 \mathrm{a}$ & $6.7 \pm 0.4 \mathrm{~b}$ & $6.5 \pm 0.2 \mathrm{C}$ \\
Mucosa thickness (MT) & $1234.12 \pm 21.2 \mathrm{a}$ & $1464.21 \pm 45.3 \mathrm{~b}$ & $1233.98 \pm 20.7 \mathrm{a}$ \\
\hline
\end{tabular}

Data represent means from 10 replicates per treatment, SEM = Standard error of mean.

Means with different superscript letters in the same line differ significantly

increased in duodenum, mid and distal jejunum and ileum in the group with supplementation of $2 \%$ zeolite, whilst a significant decrease was observed only in the proximal jejunum in this experimental group compared to the control. In the group receiving 3\% zeolite there was found a significant increase only in the distal part of jejunum and significance decreased in the proximal part of jejunum in this group compared to the control. In the case of the ratios of villus height:crypth depth $(\mathrm{VH} / \mathrm{CD})$ there was observed a significant increase only in duodenum and a significant decrease in proximal jejunum and ileum in broilers chicken which received dietary supplementation of $2 \%$ zeolite compared to the control. In the group with 3\% zeolite there was observed a significant increase only in distal jejunum whereas a significant decrease was found in proximal, mid jejunum and ileum compared to the control (Tables 3-7).

Supplementation of $3 \%$ zeolite induced a significant decrease in the total protein content in mucosa of proventriculus, duodenum, proximal jejunum, mid jejunum, distal jejunum and in pancreas. The tendency to decrease the total protein content was also observed in broilers that were fed diet with $2 \%$ zeolite compared to the control (Table 8).

Diet supplementation of zeolite stimulates the increase of gastric enzymes activity. After supplementation of zeolite in both experimental

Table 8 - Effects of Zeolite (clinoptilolite) on total protein content.

\begin{tabular}{lccc}
\hline & Control & $2 \%$ & $3 \%$ \\
\hline Proventiculus & $246.8 \pm 11.3 \mathrm{a}$ & $233.57 \pm 5.23 \mathrm{a}$ & $207.6 \pm 20.5 \mathrm{~b}$ \\
Pancreas & $478.3 \pm 28.6 \mathrm{a}$ & $425.3 \pm 30.2 \mathrm{a}$ & $417.5 \pm 12.77 \mathrm{~b}$ \\
Duodenum & $545.1 \pm 22.6 \mathrm{a}$ & $537.8 \pm 15.86 \mathrm{a}$ & $455.1 \pm 17.8 \mathrm{~b}$ \\
Proximal jejunum 25\% & $607.5 \pm 17.05 \mathrm{a}$ & $561.6 \pm 27.24 \mathrm{a}$ & $500.4 \pm 30.3 \mathrm{~b}$ \\
Mid jejunum 50\% & $606.8 \pm 21.7 \mathrm{a}$ & $577.28 \pm 15.4 \mathrm{a}$ & $432.3 \pm 20.5 \mathrm{~b}$ \\
Distal jejunum 75\% & $598.6 \pm 34.5 \mathrm{a}$ & $558.28 \pm 33.03 \mathrm{a}$ & $469.8 \pm 20.9 \mathrm{~b}$ \\
\hline
\end{tabular}

Data represent means from 10 replicates per treatment, SEM = Standard error of mean.

Means with different superscript letters in the same line differ significantly 
Wawrzyniak A, Kapica M, Stępień-Pyśniak D, Szewerniak R, Olejarska A, Jarosz $t$
Effect of Feeding Transcarpathian Zeolite on Gastrointestinal Morphology and Function in Broiler Chickens groups there were observed a statistically significant increase in the activity of pancreatic trypsin and lipase compared to the control.

Maltase activity increased in duodenum, mid and distal part of jejunum in the broilers that were fed diet with 3\% zeolite compared to the control (Table 9).
The small intestine is one of the most important sites of nutrient absorption. It has been suggested that long villi results in the increased surface area and they are capable of greater absorption of available nutrients (Caspary, 1992). Long villi were reported in chickens (Samanya \& Yamauchi, 2002, Maneewan \& Yamauchi,

Table 9 - Effects of Zeolite (clinoptilolite) on enzymes activity.

\begin{tabular}{lcccc}
\hline & & Control & $2 \%$ & $3 \%$ \\
\hline Proventriculus & Pepsin & $7.05 \pm 1.16 \mathrm{a}$ & $7.66 \pm 0.56 \mathrm{a}$ & $7.95 \pm 1.87 \mathrm{a}$ \\
Pancreas & Amylase & $1.96 \pm 0.17 \mathrm{a}$ & $2.15 \pm 0.16 \mathrm{a}$ & $2.12 \pm 0.05 \mathrm{a}$ \\
& Lipase & $5.36 \pm 0.52 \mathrm{a}$ & $8.85 \pm 1.15 \mathrm{~b}$ & $8.82 \pm 1.32 \mathrm{~b}$ \\
Duodenum & Trypsin & $2.93 \pm 0.38 \mathrm{a}$ & $6.39 \pm 1.063 \mathrm{~b}$ & $6.93 \pm 0.71 \mathrm{~b}$ \\
Prox jejunum & & $1.09 \pm 0.066 \mathrm{a}$ & $1.04 \pm 0.08 \mathrm{a}$ & $1.2 \pm 0.09 \mathrm{~b}$ \\
Mid jejunum & & $1.12 \pm 0.12 \mathrm{a}$ & $1.02 \pm 0.04 \mathrm{a}$ & $1.11 \pm 0.07 \mathrm{a}$ \\
Distal jejunum & Maltase & $1.44 \pm 0.18 \mathrm{a}$ & $1.45 \pm 0.07 \mathrm{a}$ & $1.66 \pm 0.06 \mathrm{~b}$ \\
\hline
\end{tabular}

Data represent means from 10 replicates per treatment, SEM = Standard error of mean.

Means with different superscript letters in the same line differ significantly

2004) and piglets (Zijlstra et al., 1996) that showed an increased body weight gain. Intestinal morphology was markedly affected by the fed diets (Langhout et al., 1999, Yasar \& Forbes, 1999), and the micronutrient content in feed also influenced the morphology of intestines (lji et al., 2001).

Different mechanisms have been offered to explain the effect of zeolite on the digestive and productive results of the animals. It has been reported that the addition of clay to the feedstuffs improved the nutrient digestibility and the enzymatic activity of gastrointestinal secretions (Ouhida et al., 2000, Alzueta et al., 2002). Many experiments have shown that the dietary inclusion of zeolite improves the average daily gain and feed conversion in pigs (Papaioannou et al., 2004), calves (Step et al., 2008), sheep (AlcalaCanto et al., 2011) and broilers (Suchy et al., 2006). When clinoptilolite is used as a feed supplement, the utilization of feed nutrients is increased (Olver, 1997). Numerous reports indicate that zeolite is harmless as a component of mixed feed. It is tolerated well by the animals and improves the production characteristics of broilers (Elliot \& Edwards, 1991, Trckova et al., 2004, Incharoen et al., 2010a). In our experiments, supplementation with zeolite has had significant ( $p>0.05)$ effects on productive parameters compared to the control (data unpublished). Zeolite has a crystal structure (Coombs et al., 1997, Mumpton, 1999) and might induce hypertrophied intestinal villi, resulting in improved body weight gain (Incharoen et al., 2010b, Khambualai et al., 2009). The gut morphology was affected in the sense of increased villus height and villus to crypt depth which suggests that the health of the intestine was improved by the zeolite. The number of the villus is directly related to the shape, height and surface area of the villus (Maneewan \& Yamauchi, 2005). Some authors reported that there exists a correlation between the villus structure (villus height, crypt depth, villus area, cell area) and nutrient absorption, in different regions of small intestine (Wu et al., 2013a, Wu et al., 2013b, Khambualai et al., 2009). In our experiments a tendency towards increased villus height, villus perimeter and villus section area was observed in duodenum, mid jejunum and ileum throughout the intestinal parts of broilers fed $2 \%$ zeolite compared to the control. Our study has shown that zeolite stimulates greater villus (height, perimeter, section area) in duodenum and ileum mucosa. These results indicate that the function of the intestinal villi was increased. A diet with zeolite seems to be more effectively absorbed from the intestinal villus of the duodenum than from other parts. The greater villus height and numerous mitotic cells in the intestine are the indicators that the function of the intestinal villi is activated (Langhout et al., 1999, Yasar \& Forbes, 1999, Incharoen et al., 2010a). These functions of zeolite might induce hypertrophied intestinal villi and epithelial cells (Khambualai et al., 2009). Incharoen et al. (Incharoen et al., 2010b, Incharoen et al., 2010a) reported that in the zeolite groups most light microscopic parameters (cell area, cell mitosis number) were higher than those of the controls. There were observed increases in the villus height as well as in the villus height to crypt depth ratio in the jejunal and 
Wawrzyniak A, Kapica M,

Stępień-Pyśniak $D$, Szewerniak $R$,

Olejarska A, Jarosz $t$
Effect of Feeding Transcarpathian Zeolite on Gastrointestinal Morphology and Function in Broiler Chickens ileal mucosa of the broiler chicks supplemented with zeolite. The crypt can be regarded as the villus factory and a large crypt indicates fast tissue turnover and a high demand for a new tissue (Ma \& Guo, 2008). The diet of $2 \%$ zeolite induced hypertrophy of intestinal villi providing the increase of absorptive efficiency. Histologically, it has been suggested that long villi result in an increased surface area that is capable of greater absorption of available nutrients (Caspary, 1992, Langhout et al., 1999). It has been reported that the increased villus height, in the intestine can be regarded as an indicator that the function of the intestinal villi is activated. The histological and morphometric results of this study have revealed that the intestinal response to the zeolite diets varies depending on the region of the small intestine. The dietary inclusion of zeolite improves growth performance not only in broilers but also in ducks and it has beneficial effects on egg weight and egg production (Herzig et al. 2008 ). As a feed additive, zeolite increases flow ability to retain ammonium ions $\left(\mathrm{NH}_{4}^{+}\right)$and $\mathrm{NH}_{3}$ gas in the digestive system. The findings of Maneewan and Yamauchi (Maneewan \& Yamauchi, 2005) showed that there is a positive relation between the body weight and villus height in broilers. The condition of intestinal villi is a reliable indicator of nutrient absorption from the feed ingredients in chickens (Maneewan \& Yamauchi, 2005) and in pigs (Mekbungwan \& Yamauchi, 2004). An increase in villus height and crypt depth in the small intestinal mucosa of broilers fed on the diets including zeolite was observed. The villus height to the crypt depth ratio is considered to be an important criterion for estimating the approximate digestive capacity of the small intestine. A decrease in this ratio is considered deleterious for digestion and absorption, and vice versa (Montagne et al., 2003). Therefore the absorptive function might be reflected by the villus height to the crypt depth ratio in the small intestine Chou et al., (2009). The dynamic growth of digestive organs might be an adaptive reaction to the changes in a broiler's diet. Some authors suggest that clinoptilolite affects positively the digestive mechanism and activity of digestive enzymes (Tepe et al., 2004). The ion exchange properties of the zeolite change the $\mathrm{pH}$ and ionic composition of gastrointestinal fluids, thereby changing the enzymatic activity of gastrointestinal secretions (Martin-Kleiner et al., 2001). Ouhida et al. (Ouhida et al., 2000) suggest that sepiolite improves the action of digestive enzymes in the broiler chicken. In our research a significant increase of gastric as well as pancreatic and jejunum enzymes activity was observed. The rise in enzymatic activity indicates the increased ability of the digestive tract and this results in better utilization of feed and faster weight gain of broiler chickens.

Thus, it can be concluded that the presented results are in line with the general prediction of symmorphosis, namely that all gut components develop in a coordinated manner in response to the demand for digestion and absorption. Safaeikatouli et al. (Safaeikatouli et al., 2011) suggest that zeolite can stimulate villi of the small intestine and act as a mucus stabilizer, attaching effectively to the mucus to reinforce the intestinal mucosal barrier. Zeolite can strengthen the regeneration of the epithelium, reducing, in consequence, intestinal colonization and infectious processes (Wu et al., 2013a, Wu et al., 2013b). Olver (Olver, 1997) reports that natural zeolites reduce colony counts in the gut microflora of the proximal and distal gut and reduced mortality in broilers and layers. Moreover, it is reported that zeolite acts effectively attaching to the mucus to preserve the mucosa from the toxic effects of drugs and toxins (Albengres et al., 1985). The research suggests that the intestinal villi might be activated by feeding zeolite (Wu et al., 2013a, Wu etal., 2013b). The improvement in the morphology of the intestinal mucosa may be explained by the lower numbers of E. coli and Salmonella. This ultimately decreases inflammatory processes at the intestinal mucosa, increasing, at the same time, villus height and secretory activity (Wu et al., 2013b).

These studies contain a comprehensive analysis of a large number of morphological parameters and numerous enzymatic analyses which show the dynamics of changes in the gut under the conditions of Transcarpathian zeolite supplementation.

The histological study has demonstrated that dietary zeolite supplementation improves growth and intestinal morphology of broilers. Morphological changes were detected after administration of zeolite, especially with $2 \%$ supplementation in feed. There is observed an increase in the number of villi, their height and perimeter as well as in villus section area in duodenum and ileum mucosa in the broiler chickens. This improvement was achieved through increasing the secretion of digestive enzymes, enhancing the digestibilites of nutrients, promoting intestinal health of broiler chickens. Using the zeolite supplementation has nutritional advantages and suggests a beneficial effect on small intestine quality. These results indicate, that dietary zeolite can be used as a natural feed additive to stimulate morphological of the intestinal villi, in consequence, intestinal function, and it is an effective alimentation for broilers diets. The exact 
Wawrzyniak A, Kapica M,

Stępień-Pyśniak D, Szewerniak R,

Olejarska A, Jarosz $t$
Effect of Feeding Transcarpathian Zeolite on Gastrointestinal Morphology and Function in Broiler Chickens molecular mechanism of how zeolite affects the animals is still unknown. Further research is needed to elucidate the direct effects of zeolite on morphology and physiology of small intestine in poultry.

\section{Competing interests}

The authors declare that there is no conflict of interest that could be perceived as prejudicing the impartiality of the research reported.

\section{ACKNOWLEDGEMENTS}

The authors thank for KAWA. SKA company for permission to use Leica Technology equipment. Thanks to Andalusia company for free access to Transcarpathian zeolite in our research. Thank you Mr. Dmytro Petushynskyy for providing information on the physico-chemical properties of the zeolite used for our research. This study was supported by the grant of University of Life Sciences in Lublin, Poland.

All authors approved the final manuscript.

\section{REFERENCES}

Albengres E, Urien S, Tillement JP, Oury P, Decourt S, Flouvat B et al. Interactions between smectite, a mucus stabilizer, and acidic and basic drugs. In vitro and in vivo studies. European Journal Clinical Pharmacology 1985;28:601-605.

Alcala-Canto Y, Gutierrez-Olvera L, Gutierrez-Olvera C, Sumano-Lopez $\mathrm{H}$. Effects of clinoptilolite on Eimeria spp. Infection in sheep. Small Ruminant Research 2011;100: 184-188.

Alzueta C, Ortiz LT, Rebole A, Rodriguez ML, Centeno C. Trevino J. Effects of removal of mucilage and enzyme or sepiolite supplement on the nutrient digestibility and metabolyzable energy of a diet containing linseed in broiler chickens. Animal Feed Science and Technology 2002;97:169-181.

Caspary WF. Physiology and pathophysiology of intestinal-absorption. American Journal of Clinical Nutrition 1992;55:299-308.

Chou SH, Chung TK, Yu B. Effects of supplemental 25-hydroxycholecalciferol on growth performance, small intestinal morphology, and immune response of broiler chickens. Poultry Science 2009;88(11):2333-2341.

Coombs DS, Alberti A, Armbruster T, Artioli G, Colella C, Galli E, et al. Recommended nomenclature for zeolite minerals: Report of the subcommittee on zeolites of the International Mineralogical Association, Commission on New Minerals and Mineral Names. Canadian Mineralogist 1997;35:1571-1606.

Dahlqvist A. Assay of intestinal disaccharidases. Scandinavian Journal of Clinical and Laboratory Investigation 1984;44:169-72.

Elliot MA, Edwards HM. Comparison of the effects of synthetic and natural zeolite on laying hen and broiler chicken performance. Poultry Science $1991 ; 70: 2115-2130$

Herzig I, Strakova E, Suchy P. Long-term application of clinoptilolite via the feed of layers and its impact on the chemical composition of long bones of pelvic limb (femur and tibiotarsus) and eggshell. Veterinarni Medicina 2008:53:550-554. lji PA, Saki A, Tivey DR. Body and intestinal growth of broiler chicks on a commercial starter diet. 1. Intestinal weight and mucosal development. British Poultry Science 2001;42:505-513.

Incharoen T, Yamauchi K, Erikawa T, Gotoh H. Histology of intestinal villi and epithelial cells in chickens fed low-crude protein or low-crude fat diets. Italian Journal of Animal Science 2010a;9:429-434.

Incharoen T, Yamauchi K, Thongwittaya N. Intestinal villus histological alterations in broilers fed dietary dried fermented ginger. Journal of Animal Physiology and Animal Nutrition 2010b;94:e130-e137.

Khambualai O, Ruttanavut J, Kitabatake M, Goto H, Erikawa T, Yamauchi K. Effects of dietary natural zeolite including plant extract on growth performance and intestinal histology in Aigamo ducks. British Poultry Science 2009;50:123-130.

Kotunia A, Wolinski J, Laubitz D, Jurkowska M, Rome V, Guilloteau P, et al. Effect of sodium butyrate on the small intestine development in neonatal piglets fed [correction of feed] by artificial sow. Journal Physiology and Pharmacology 2004;55(Suppl 2):59-68.

Langhout DJ, Schutte JB, Van Leeuwen P, Wiebenga J, Tamminga S. Effect of dietary high- and low-methylated citrus pectin on the activity of the ileal microflora and morphology of the small intestinal wall of broiler chicks. British Poultry Science 1999; 40:340-347.

Ma YL, Guo T. Intestinal morphology, brush border and digesta enzyme activities of broilers fed on a diet containing Cu2+-loaded montmorillonite. British Poultry Science 2008;49:65-73.

Maneewan B, Yamauchi K. Intestinal villus recovery in chickens refed semipurified protein-, fat-, or fibre-free pellet diets. British Poultry Science 2004; $45: 163-170$

Maneewan B, Yamauchi K. Recovery of duodenal villi and cells in chickens refed protein, carbohydrate and fat. British Poultry Science 2005;46:415-423.

Martin-Kleiner I, Flegar-Mestric Z, Zadro R, Breljak D, Stanovic Janda $\mathrm{S}$, Stojkovic R, et al. The effect of the zeolite clinoptilolite on serum chemistry and hematopoiesis in mice. Food Chemical Toxicology 2001;39:717-727

Matyjek R., Kapica M., Puzio I., Bąbelewska M., Zabielski R.: The effect of fundectomy on pancreatic secretion in anaesthetized rats. Journal of Physiology and Pharmacology 2004, 55, Suppl 2, 69-75.

Mekbungwan A, Yamauchi K. Growth performance and histological intestinal alterations in piglets fed dietary raw and heated pigeon pea seed meal. Histology Histopathology 2004;19:381-389.

Montagne L, Pluske JR, Hampson DJ. A review of interactions between dietary fibre and the intestinal mucosa, and their consequences on digestive health in young non-ruminant animals. Animal Feed Science and Technology 2003;108:95-117.

Mumpton FA. La roca magica: uses of natural zeolites in agriculture and industry. Proceedings of the National Academy of Sciences of the United States of America 1999;96:3463-3670.

Olver MD. Effect of feeding clinoptilolite (zeolite) on the performance of three strains of laying hens. British Poultry Science 1997;38:220-222.

Ouhida I, Perez J, Piedrafita J, Gasa J. The effects of sepiolite in broiler chicken diets of high, medium and low viscosity. Productive performance and nutritive value. Animal Feed Science and Technology 2000;85:183-194.

Papaioannou DS, Kyriakis CS, Alexopoulos C, Tzika ED, Polizopoulou ZS, Kyriakis SC. A field study on the effect of the dietary use of a clinoptiloliterich tuff, alone or in combination with certain antimicrobials, on the health status and performance of weaned, growing and finishing pigs. Research in Veterinary Science 2004;76:19-29. 
Papaioannou DS, Kyriakis S C, Papasteriadis A, Roumbies N, Yannakopoulos A, Alexopoulos C. Effect of in-feed inclusion of a natural zeolite (clinoptilolite) on certain vitamin, macro and trace element concentrations in the blood, liver and kidney tissues of sows. Research in Veterinary Science 2002;72:61-68.

Pavelic K, Hadzija M, Bedrica L, Pavelic J, Dikic I, Katic M, et al. Natural zeolite clinoptilolite: new adjuvant in anticancer therapy. Journal of Molecular Medicine 2001;78:708-720

Safaeikatouli M, Jafariahangari Y, Baharlouei A. An evaluation on the effects of dietary kaolin and zeolite on broilers blood parameters, T4, TSH and growth hormones. Journal of Animal and Veterinary Advances 2011:10:10-14

Samanya M, Yamauchi, K. Histological alterations of intestinal villi in chickens fed dried Bacillus subtilis var. natto. Comparative Biochemistry and Physiology a- Molecular and Integrative Physiology 2002;133:95104.

Step DL, Litherland NB, Burciaga-Robles LO, Breshears MA, Krehbiel CR, Confer AW, et al. Clinical observations, biochemical data, and postmortem and histopathologic findings in young dairy calves fed zeolite clinoptilolite binder combined with milk replacer. American Journal of Veterinary Research 2008;69:1587-1594.

Suchy P, Strakova E, Vecerek V, Klouda Z, Kracmarova E. The effect of a clinoptilolite-based feed supplement on the performance of broiler chickens. Czech Journal of Animal Science 2006;51:168-173.

Tepe Y, Akyurt I, Ciminli C, Mutlu E, Caliskan M. Protective effect of clinoptilolite on lead toxicity in common carp Cyprinus carpio. Fresenius Environmental Bulletin 2004;13:639-642.
Trckova M, Matlova L, Dvorska L, Pavlik I. Kaolin, bentonite, and zeolites as feed supplements for animals: health advantages and risks. Veterinarni Medicina 2004;49: 389-399.

Ural DA, Cengiz O, Ural K, Ozaydin S. Dietary clinoptilolite addition as a factor for the improvement of milk yield in dairy cows. Journal of Animal and Veterinary Advances 2013;12(1):85-87.

Valpotic H, Terzic S, Vince S, Samardzija M, Turk R, Lackovic G, et al. In-feed supplementation of clinoptilolite favourably modulates intestinal and systemic immunity and some production parameters in weaned pigs. Veterinarni Medicina 2016;61:317-327.

Wislinski M, Popielarz M, Bobowiec R. Prochymosin polymorphism in calves of black-and-white cattle and their crosses with Simental bulls. Zentralblatt Fur Veterinarmedizin. Reihe A 1995;42:389-396.

Wu QJ, Wang LC, Zhou YM, Zhang JF, Wang, T. Effects of clinoptilolite and modified clinoptilolite on the growth performance, intestinal microflora, and gut parameters of broilers. Poultry Science 2013a;92:684-692.

Wu QJ, Zhou YM, Wu YN, Wang T. Intestinal development and function of broiler chickens on diets supplemented with clinoptilolite. AsianAustralasian Journal of Animal Sciences 2013b;26:987-994.

Yasar S, Forbes JM. Performance and gastro-intestinal response of broiler chickens fed on cereal grain-based foods soaked in water. British Poultry Science 1999;40:65-76.

Zijlstra RT, Whang KY, Easter RA, Odle J. Effect of feeding a milk replacer to early-weaned pigs on growth, body composition, and small intestinal morphology, compared with suckled littermates. Journal of Animal Science 1996;74:2948-2959. 